\title{
Pattern and Management of Priapism in a Tertiary Hospital of North- Western Nigeria
}

\author{
A S Muhammad ${ }^{1}$, N P Agwu ${ }^{1}$, A Abdulwahab-Ahmed ${ }^{1}$, S B Abubakar ${ }^{2}$, \\ A U Musa ${ }^{2}$, I A Mungadi ${ }^{1}$ \\ ${ }^{1}$ Urology Unit, Department of Surgery, Usmanu Danfodiyo University Teaching \\ Hospital Sokoto, Nigeria. \\ ${ }^{2}$ Department of Haematology and Blood Transfusion, Usmanu Danfodiyo \\ University Teaching Hospital Sokoto, Nigeria.
}

Correspondence to: Dr. M A Sadiq, E-mail: asmgusau@gmail.com https://dx.doi.org/10.4314/ecajs.v22i1.9

Background: Priapism is a persistent penile erection that continues for more than four hours beyond sexual stimulation and orgasm or unrelated to sexual stimulation ${ }^{1}$. The objective is to document the pattern and management of priapism in our hospital.

Methods: This is a retrospective study of patients managed for Priapism by Urology Unit of our hospital, from January 2009 to December 2015.

Results: Thirty patients were managed for managed for priapism within the study period. The mean age at presentation was $23.9 \pm 12.2$ years with a range of $8-55$ years. Fifteen patients (57.7\%) presented beyond 72 hours of the onset of priapism. All the patients had ischaemic priapism. Half of the patients had sickle cell disease, two (7.7 \%) had chronic myeloid leukaemia, five (19.2\%) used aphrodisiacs and cause was not established in six (23.1\%). The most effective forms of treatments were corporal aspiration and glanulocavernosal shunt. Hydroxyurea was used for the patients with leukaemia. Thirteen (50.0\%) of the patients were loss to follow-up after their first visits. Three patients (11.5\%) developed erectile dysfunction.

Conclusion: Sickle cell disease is the commonest cause of ischaemic priapism in our practice. Late presentation is common and is usually associated with the development of erectile dysfunction.

Keywords: priapism, sickle cell disease, aphrodisiacs, erectile dysfunction, treatments of ischaemic priapism

\section{Introduction}

Priapism is a persistent penile erection that continues for more than four hours beyond sexual stimulation and orgasm or unrelated to sexual stimulation ${ }^{1}$. There is dysfunction of mechanisms regulating penile tumescence, rigidity and flaccidity ${ }^{2,3}$. Priapism can be ischaemic (low flow), non-ischaemic (high flow) or stuttering ${ }^{4}$. Stuttering priapism is characterized by pattern of recurrence and historically described as unwanted painful erections in men with sickle cell anaemia ${ }^{5}$. Ischaemic priapism is a urologic emergency which requires prompt diagnosis and urgent intervention to prevent erectile dysfunction. Interventions done beyond 48 hours may only relieve the priapic state and pain but may do 
little to preserve potency ${ }^{1}$. Ischaemic priapism is painful, with little or no arterial blood flow resulting in time -dependent alteration in the corporal metabolic environment leading to progressive hypoxia, hypercabia and acidosis ${ }^{6}$. In Western world, ischaemic priapism is usually idiopathic or due to use of aphrodisiacs more especially intracavernosal injections for erectile dysfunction 7,8 while haematological disorders, more especially sickle cell disease, are the commonest cause in our environment ${ }^{9,10}$. Aghaji et al ${ }^{11}$ reported use of aphrodisiacs to be the commonest cause in Nigerian adults but more recent studies by Badmus et al ${ }^{9}$, Ajape et al ${ }^{12}$, Omisanjo et al ${ }^{13}$ and Ekeke et al ${ }^{10}$ showed sickle cell disease to be the commonest aetiologic factor in Nigeria. We carried out this study to document the pattern and management of priapism in our institution.

\section{Patients and Methods}

Records of patients managed for priapism at Urology Unit, Department of Surgery, of our hospital, from January 2009 to December 2015 were retrospectively retrieved. The following information was extracted; socio-demographic features, presentation, duration of symptoms before presentation, type of priapism, aetiology of priapism, clinical examination findings, results of laboratory investigations, treatment offered, and duration of admission and complications. The laboratory investigations include haemoglobin genotype, peripheral blood film, full blood count and electrolyte urea and creatinine. Data was entered into a structured proforma and analysed using SPSS version 20.0 for windows.

\section{Results}

Thirty patients were managed for priapism within the study period, but full records of only 26 patients were retrieved. The mean age of the patients was $23.9 \pm 12.2$ years (8- 55 years). Only eight patients $(30.8 \%)$ presented within 24 hours of the onset of priapism. Of the 18 patients $(69.2 \%)$ that presented beyond 24 hours, six $(23.1 \%)$ presented after a week (Table 1). The mean duration of priapism was $110.6 \pm 91.9$ hours. Twenty four patients (92.3\%) had hard woody penis with dark tarry blood aspirated from the corpora. Two patients $(7.7 \%)$ had stuttering priapism and the penis was flaccid at presentation.

Table 1. Duration of Priapism before Presentation

\begin{tabular}{|l|c|c|}
\hline Duration of symptoms & Number of patients & Percentage \\
\hline 24 hours & 8 & 30.8 \\
\hline $24-48$ hours & 3 & 11.5 \\
\hline 72 hours & 5 & 19.2 \\
\hline 72 hours- 1 week & 4 & 15.4 \\
\hline$>1-2$ weeks & 6 & 23.1 \\
\hline Total & 26 & 100.0 \\
\hline
\end{tabular}


Table 2. Aetiology of Priapism in our environment

\begin{tabular}{|l|c|c|}
\hline Aetiology & Number of patients & Percentage \\
\hline Sickle Cell Disease & 13 & 50.0 \\
\hline Chronic Myeloid Leukaemia & 2 & 7.7 \\
\hline Idiopathic & 6 & 23.1 \\
\hline Aphrodisiacs & 5 & 19.2 \\
\hline Total & $\mathbf{2 6}$ & $\mathbf{1 0 0 . 0}$ \\
\hline
\end{tabular}

All the 26 patients had ischaemic or low flow priapism. The commonest aetiologic factor was haematologic disorders which were found in 13 patients $(57.7 \%)$. Of the five patients $(19.2 \%)$ that used aphrodisiacs, two used overdose of sildinafil citrate and three used herbs to enhance their sexual performances. Other details of the aetiologic factors were shown in Table 2.

All the patients were counseled about the disease, possible outcomes and that even though intervention may relieve pain and priapic state, it does little in preservation of potency. Erectile dysfunction may occur later more especially in those that presented after 48 hours. Corporal aspiration with or without irrigation, percutaneous shunts, caveroglandular shunt were performed for thirteen (50\%), three (11.5\%) and ten patients (38.5\%) (Table 3 ). Twenty two patients (84.6\%) had immediate detumescence following surgical intervention. Four patients $(15.4 \%)$ with minimal or no detumescence after the intervention had penile fibrosis and oedema. In the 2 patients (7.7\%) with CML, initial corporal aspiration and irrigation was not effective, but they had detumescence after cytoreduction with hydroxyuria. Two patients (7.7\%) refused caverno-glandular shunt and left against medical advice after corporal aspiration and irrigation with partial detumescence. Other details of surgical interventions are shown below (Table 3)

Table 3. Surgical Interventions for Priapism

\begin{tabular}{|l|c|c|}
\hline Intervention & Frequency & Percent \\
\hline corporal aspiration & 5 & 19.2 \\
\hline Corporal aspiration + irrigation & 8 & 30.8 \\
\hline Winters shunt (percutaneous) & 2 & 7.7 \\
\hline Caverno-glandular shunt (AL-ghorab ) & 10 & 38.5 \\
\hline Ebbehoj shunt (percutaneous) & 1 & 3.8 \\
\hline Total & $\mathbf{2 6}$ & $\mathbf{1 0 0 . 0}$ \\
\hline
\end{tabular}


Erectile dysfunction and high flow priapism occurred in 3 patients (11.5\%) and 1 patient (3.8\%) respectively. The mean duration of admission was ( 7 days \pm 1.5 days). Nine patients (34.6\%) did not return for follow-up after discharge, and 13 patients $(50.0 \%)$ were loss to follow-up after the first visit. The longest follow-up was five years in a patient with erectile dysfunction.

\section{Discussion}

Ischaemic priapism is a urologic emergency and a form of compartment syndrome that requires immediate corporal decompression to prevent corporal ischaemia, acidosis, fibrosis and subsequent erectile dysfunction. It affects young age group in our environment with significant negative impact on their quality of life. The mean age of our patients was 23.9 years which was comparable to 25.4 years and 20.4 years reported by Omisanjo et al ${ }^{13}$ and Badmus et al ${ }^{9}$ in the South- Western part of Nigeria. Ekeke et al ${ }^{10}$ who studied adult population in Port- Harcourt reported median age of 30 years. All our patients were male and had ischaemic priapism as reported by the previous studies ${ }^{9-13}$. Clitoral priapism is rare, 3,10 and we did not record it in our series. Some researchers suggested high incidence of female genital mutilation to be a factor in a rarity of clitoral priapism ${ }^{10}$.

The risk factors for it, such as use of specific classes of medications (alpha adrenergic blockers, antidepressants), diseases that alter clitoral blood flow and clitoral vascular anomalies leading to clitoral engorgement such as Persistent Genital Arousal Disorder (PGAD) are rare in our environment ${ }^{3,14,15}$. The mean time of presentation in this study (110 hours)was longer than what was reported by Omisanjo et ${ }^{13}$ al (74.4 hours) but shorter than other studies by Badmos et al ${ }^{9}$ (192 hours) and Ekeke et al ${ }^{10}$ (144 hours). Generally, patients in our environment present after 48 hours unlike what happened in the Western World where patients usually present within 24 hours ${ }^{10}$. Even though our intervention relieved the acute pain, it did little in preserving the potency. Therefore, the patients in the long run are predisposed to the development of erectile dysfunction which was recorded in only three of the patients probably due to poor follow-up. These patients had evidence of penile fibrosis on presentation. The patients could not present early despite painful erection due to cultural inhibition about sexual matters, ignorance and poverty. A good number of them presented initially to general practitioners, chemists, herbalists and peripheral hospital before referral to our facility. In Pohl's series ${ }^{16}$ delay of five days between the onset and intervention did not affected the prognosis much. He reported that $65 \%$ and $40 \%$ regained potency when intervention was instituted between five and ten days of the onset of priapism.

Some of our patients were newly married young men that took herbs and overdose of sildinafil citrate to enhance sexual performance. It is a tradition in this environment to use all kinds of herbs and concoctions by newly married individuals male and females to enhance sexual performance. This preserves self esteem and continuity of marriage as the first coitus reflects the man's potency.

The commonest aetiologic factor in our series was haematologic disorder (57.7\%) with sickle cell disease alone accounting for $50 \%$ of the cases. This was similar to the findings by

COSECSA/ASEA Publication -East \& Central African Journal of Surgery 2017; Vol. 22 (1) 


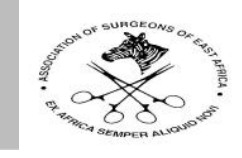

Badmus et ${ }^{9}$ al, Omisanjo et al ${ }^{16}$, Ekeke et al where sickle cell disease accounted for $87.6 \%$, $63 \%$ and $55.6 \%$ of their cases respectively. In Ekeke series ${ }^{9}$ haematological disorders accounted for $66.7 \%$ of the ischaemic priapism, where as in our study they accounted for $57.7 \%$ of our patients. These comprise sickle cell disease and CML in the two studies. Idiopathic causes and use of aphrodisiacs predominates in Southern Nigeria and Europe, accounted for $19 \%$ and $23 \%$ of our patients respectively.

Corporal aspiration was less affective(42.3\%) in our series compared to the one reported by Omisanjo et al ${ }^{13}$ (78.3\%). This difference can be accounted for by the late presentation in our patients and thus presence of corporal injury and oedema. Lawani et al ${ }^{17}$ reported cavernotomies to be effective. Al-ghorab shunt was effective in all the ten patients that had the procedure in our series. This is a procedure of choice when aspiration and percutaneous shunt failed which is common in late presentation. The average duration of admission of our patients was seven days which was longer than 5.8 days reported by Omisanjo et al ${ }^{13}$. Some of the patients need longer admission to allow for resolution penile oedema and turgidity following intervention. The patients with CML stayed up to two weeks on hospital admission due the time required to achieve effective cytoreduction and to establish appropriate maintenance dose for hydroxyuria by the haematologist.

Only 13 patients $(50.0 \%)$ reported for follow up at the first visit while the rest were loss to follow-up. This is similar to what we observed in the follow up of other urologic diseases. Most of the patients are poor, ignorant and cover long distance before they reach our facility. Our patients come regularly for follow-up when they have complaints. Erectile dysfunction was seen only in three patients (11.5\%) which might be accounted by erratic follow-up. Most of these patients are young, not yet sexually active which makes the complaints of erectile dysfunction less worrisome. They may later represent to other physicians with erectile dysfunction after getting married or when sexually active. Bertolotto et al ${ }^{18}$ reported a case of high flow priapism following Winter shunt due to injury to dorsal artery. This rare complication was observed in one patient in our series which was managed conservatively. He had initial corporal aspiration which we thought had failed and he subsequently had Al-ghorab shunt. The patient was one of those patients that did not report for any follow-up visit.

\section{Conclusion}

Haematologic disorders are the commonest cause of priapism in our environment. The most effective forms of treatments were corporal aspiration and distal shunt. The mean time of presentation of our patients was late with attendant susceptibility to erectile dysfunction. This complication is likely to have been under reported in our series due to erratic follow-up by the patients.

\section{References}

1. Gregory A, Broderich MD. Priapism. In: Wein AJ, Partin AW PC, editor. Campbell Walsh's Urology. 11th ed. Philadelphia: Elsevier, Incorporation; 2016:2121-75.

2. Anele UA, Morrison BF, Burnett AL. Molecular pathophysiology of priapism: emerging 
targets. Curr Drug Targets. 2015;16:474-83.

3. Yafi FA, April D, Powers MK, Sangkum P, Hellstrom WJG. Penile Priapism, Clitoral Priapism, and Persistent Genital Arousal Disorder: A Contemporary Review. Sex Med Rev. 2015;3:145-59.

4. Shigehara K, Namiki M. Clinical Management of Priapism: A Review. World J Mens Health. 2016;34:1-8.

5. Kheirandish $\mathrm{P}$, Chinegwundoh F, Kulkarni S. Treating stuttering priapism. BJU International. 2011:1068-1072.

6. Kovac JR, Mak SK, Garcia MM, Lue TF. A pathophysiology-based approach to the management of early priapism. Asian J Androl. 2013;15:20-26.

7. Gregory AB, Ates K, Trinity JB, Hussein G, Ajay N, Rany S. Priapism: pathogenesis, epidemiology and management. J Sex Med. 2010;7:476-500.

8. Salonia A, Eardley I, Giuliano F, Hatzichristou D, Moncada I, Vardi Y, et al. European association of urology guidelines on priapism. Eur Urol. 2014;65:480-489.

9. Badmus TA, Adediran IA, Adesunkanmi ARK, Katung IA. Priapism in southwestern Nigeria. East Afr Med J. 2003;80:518-524.

10. Ekeke ON, Omunakwe HE, Eke N. Management of Priapism in Adult Men. Int Surg. 2015;100:552-557.

11. Aghaji AE. Priapism in adult Nigerians. BJU Int. 2000;85:493-495.

12. Ajape AA, Babata A, Shiitu AO, Olatoke SA, Abiola OO. Clinical Presentation and Management of Priapism in Nigerian Tertiary Institution. 2009;1(4):103-6.

13. Omisanjo O, Ikuerowo S, Abdulsalam AA, Esho J. Clinical Characteristics And Outcome Of Management Of Priapism At The Lagos State University Teaching Hospital. Internet J Urol. 2012;9:1-5.

14. Medina CA. Clitoral priapism: a rare condition presenting as a case of vulvar pain. Obs Gynaecol. 2002;100:1089-1091.

15. Gharahbaghaian L. Clitoral priapism with no known risk factor. West J Emerg Med. 2008;9:235-237.

16. Pohl J, Pott B, Kleinhans G. Priapism: a three- phase concept of management according to aetiology and prognosis. Br J Urol. 1986;58:113-118.

17. Lawani J, Aken'Ova YA, Shiitu O. Priapism: an appraisal of surgical treatment. Afr J Med Sci. 1999;28:21-23.

18. Bertolotto M, Ciampalini S, Martingano P, Pozzi MF. High Flow Priapism Complicating Low Flow Priapism Following latrogenic Laceration of Dorsal Artery of Penis during a Winter Procedure. J Clin Ultrasound. 2009;37:61-64. 